\title{
Influence of temperature variation on embryonic and early larval development of a commercially important tropical sea urchin Tripneustes gratilla (Linnaeus, 1758)
}

\author{
MD. SHAMIM PARVEZ ${ }^{1}$, M. AMINUR RAHMAN ${ }^{1,2}$, FATIMAH MD. YUSOFF $^{1,3}$, AZIZ ARSHAD $^{1,3}$ \\ AND SANG-GO LEE ${ }^{2}$ \\ ${ }^{1}$ Laboratory of Marine Biotechnology, Institute of Bioscience, Universiti Putra Malaysia, 43400 UPM Serdang \\ Selangor, Malaysia. \\ ${ }^{2}$ World Fisheries University Pilot Programme, Pukyong National University (PKNU), 45 Yongso-ro, Nam-gu \\ Busan 48513, Korea \\ ${ }^{3}$ Department of Aquaculture, Faculty of Agriculture, Universiti Putra Malaysia, 43400 UPM Serdang, Selangor, Malaysia \\ e-mail: aminur1963@gmail.com; aminur2017@pknu.ac.kr
}

\section{ABSTRACT}

The present study investigated the influence of different temperature levels $\left(16,19,22,25,28,31\right.$ and $\left.34^{\circ} \mathrm{C}\right)$ on embryonic and early larval development of the tropical sea urchin, Tripneustes gratilla (Linnaeus, 1758) in a controlled laboratory condition. The critical lower and higher temperature for embryonic development was found to be 16 and $34^{\circ} \mathrm{C}$, respectively. Embryos reared in these temperatures exhibited $100 \%$ abnormality within $48 \mathrm{~h}$ post-insemination. The time required to reach embryonic and larval stages was increased with temperature from $28^{\circ} \mathrm{C}$ followed by $31,25,22$ and $19^{\circ} \mathrm{C}$. The developmental time of 2 -cell to 4 -arm pluteus larvae showed significant $(\mathrm{p}<0.05)$ differences. The survival $(\%)$ of larvae at the prism, 2-arm and 4-arm stages were observed as dissimilar from 22 to $34^{\circ} \mathrm{C}$, and the highest values $(100 \%$ or near $100 \%$ ) were found at 25 and $28^{\circ} \mathrm{C}$. The morphometric measurements from prism to 4-arm pluteus larvae at different temperatures differed significantly $(\mathrm{p}<0.05)$. However among the temperatures evaluated, $28^{\circ} \mathrm{C}$ was found as the best temperature for better growth and development of larvae at all stages. The findings of the study would help to develop captive breeding and seed production programmes for commercial aquaculture of the species.

Keywords: Development, Embryo, Larva, Temperature, Tripneustes gratilla

\section{Introduction}

The average global temperature has already increased by $0.74^{\circ} \mathrm{C}$ in the last century and is estimated to increase by another $2-4^{\circ} \mathrm{C}$ by the year 2100 (IPCC, 2007). Thus, increasing temperatures have already caused several direct and indirect ecological changes including species range shifts, reduced recruitment, mass community mortalities, changes to breeding seasons and enhanced establishment of invasive species (Southward et al., 1995; Walther et al., 2002; IPCC 2007; Przeslawski et al., 2008; Gambainani et al., 2009, Graham et al., 2009; Johnson et al., 2011; Wemberg et al., 2011). In the past 60 years, the surface temperature in Australia has risen by $2^{\circ} \mathrm{C}$ and is likely to further increase by another $3^{\circ} \mathrm{C}$ by 2070 (Poloezanska et al., 2007; Figuera et al., 2010). However, ocean warming is considered to be of fast concern for south-eastern Australia.

Tripneustes gratilla (Linnaeus, 1758) (Echinodermata: Tripneustidae) or collector sea urchin, one of the commercially important regular echinoids, has a circumtropical distribution extending into the subtropics (Lawrence, et al., 2001a). It occurs most abundantly throughout the Indo-West Pacific, where it can be found from East Africa (Red Sea to Natal), the South Sea islands (from the Norfolk and Kermadec Islands to the Marquesas and Hawaii) and from Australia (to Port Jackson on the east coast and Sharks Bay on the west) to Southern Japan (with the Bonin Islands) (Lawrence et al., 2001a, b). It can also be found in the warm tropical regions including Pulau Bum near Semporna, between Sabah and Philippines (Parvez et al., 2016a, b). It is most common in shallow water habitat on a variety of hard substrates and is found at depths from 2 to $30 \mathrm{~m}$ (Lawrence et al., 2001a).

The increasing sea surface temperature affects early life stages of broadcast spawning marine invertebrates (Byrne 2010, 2012). Sea urchin is widely distributed throughout the Indo-Pacific (Lawrence et al., 2007). In addition, fertilisation and larval development of sea urchin occur within distinct temperature ranges for some species 
(O’Connor et al., 1977, Mita et al., 1984; Sewell et al., 1999). So, ocean warming is likely to be harmfully affecting these life stages.

T. gratilla is commercially important due to presence of highly rich polyunsaturated fatty acids (PUFAs). In Malaysia, sea urchin gonads are used for preparing different types of food viz., Oku-Oku or Ketupat tehe-tehe during special occasions i.e., Lepa-Lepa festival, wedding ceremony and also other events (Parvez et al., 2016b). It is also considered important for the treatment of a number of diseases such as arrhythmia, cardiovascular diseases, cancer, tumor development and light sensitivity diseases (Britton, 2004; Pulz and Gross, 2004). It is also used for improving sexual potency of human, especially the middle aged_(Seifulla et al., 1995; Yur'eva et al., 2003). T. gratilla is also important ecologically, especially in sea grass habitats and is a food source with good potential for aquaculture (Juinio-Menez et al., 1998; Dworjanyn et al., 2007; Lawrence et al., 2007; Unsworth, 2010). Early life stages (Hart, 2002) of sea urchins, in particular, are known to be highly sensitive to a wide range of environmental contaminants and stressors (Dinnel et al., 1989) which is making them ideal organisms for assessing impacts of climate change. Its life cycle has a planktonic period of days or weeks in the water column and seawater chemistry and temperature have major impacts on the development. Temperature has a major influence in shortening the planktonic period, an effect that decreases predation pressure and also alters connectivity between populations (O’Connor, 2007; Byrne et al., 2010).

Very few systematic works have been done on the abundance, distribution, breeding, development and population growth patterns of some non-commercial tropical species of echinoids (e.g., Diadema setosum and Salmacis sphaeroides) in Peninsular Malaysia (Rahman et al., 2012a, b) but no published information is available on the breeding, nursing, seed production and culture techniques of the high-valued sea urchin species, T. gratilla (Linnaeus, 1758). Due to the higher biological, ecological, aquacultural and nutritional importance of T. gratilla, it is urgently needed to develop induced breeding, larval rearing and seed production protocols in captivity (Poloczanska, 2007). Fertilisation in T. gratilla and other echinoids is robust to climate change stressors (Byrne, 2010; Byrne et al., 2011). In the present study, an attempt has been made to assess the effects of water temperature and its optimum level for embryonic and early larval development of $T$. gratilla in a controlled rearing system.

\section{Materials and methods}

\section{Sample collection and conditioning}

In total, 50 mature adults of $T$. gratilla weighing 160 to $260 \mathrm{~g}$ and measuring 80 to $112 \mathrm{~mm}$ in diameter, were collected from Bum Bum Island $\left(4^{0} 27^{\prime} 55.08^{\prime \prime} \mathrm{N}\right.$; $118^{0} 40^{\circ} 94^{\prime \prime}$ ) in Semporna, Sabah, Malaysia (Fig. 1), at low tide during their natural breeding season from January to May, 2016. The collected specimens were then transferred live to the Laboratory of Marine Biotechnology, Institute of Bioscience, Universiti Putra Malaysia (UPM), maintained in aerated closed aquaria and were used for the experiments within 3-4 days of collection.

\section{Spawning}

A total of eight pairs of sexually mature adult specimens of $T$. gratilla were used for spawning. Captive

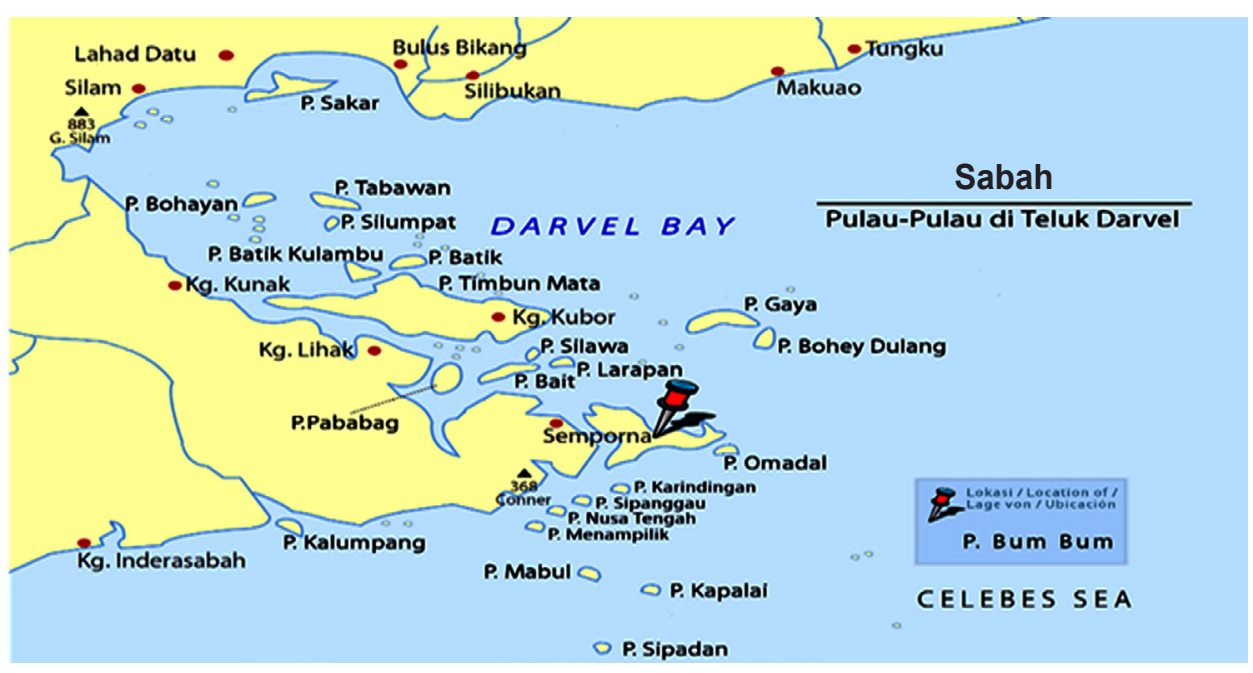

Fig. 1. Map showing sampling area of T. gratilla in Bun-Bun Island, Semporna, Sabah (Source: Parvez et al., 2016b) 
breeding was attempted by adding $2 \mathrm{ml}$ of $0.5 \mathrm{M}$ of $\mathrm{KCl}$ into the coelomic cavity of both male and female sea urchins (Rahman et al., 2000; 2005; 2012b). Later on, the eggs were collected by inverting the female to a glass beaker filled with $2 \mu \mathrm{m}$ filtered seawater (FSW). Soon after collection, the maturity and condition of eggs were checked under a compound microscope (Zeiss Axioskop 2). Good quality eggs having uniform shape and distinct nucleii were used for fertilisation experiment (Rahman and Uehara, 2004). The eggs were then washed consecutively with FSW 3-4 times in order to remove the debris and immature eggs by sucking out the supernatant seawater. Sperm from each male sea urchin were observed under a compound microscope to determine their motility (Rahman and Uehara, 2004). Only highly motile sperms were used for fertilisation trials in order to assure good fertilisation rate.

\section{Temperature trials}

The effect of temperature on embryonic and early larval development of $T$. gratilla was investigated at seven different temperature levels between 16 and $34^{\circ} \mathrm{C}$. Water baths (Thermal Robo TR-1A) equipped with cooler (TRL107NHF) and normal temperature with water flow tank in the open environment and also at room temperature were used for this experiment. Plastic falcon tubes $(50 \mathrm{ml})$ were used for the culture of embryos and for growing larvae at different temperatures. The plastic tubes were allowed to float in the water bath to make sure that the seawater inside has movement in order to prevent embryos from accumulating at the bottom.

\section{Early development}

Eggs were allowed to remain with sperm for about $20-25$ min for fertilisation at ambient temperature $\left(28^{\circ} \mathrm{C}\right)$ and transferred to $50 \mathrm{ml}$ plastic falcon tubes $(18 \mathrm{~mm}$ dia, $175 \mathrm{~mm}$ depth) at a concentration of approximately 400-500 zygotes/tube. The plastic tubes were then placed in water baths, which were pre-set at different temperatures viz., 16, 19, 22, 25, 28, 31 and $34^{\circ} \mathrm{C}$. Observations were made at: $4,8,12,24$ and $48 \mathrm{~h}$ post-insemination. At each observation time, the percentage of each embryonic stage at different temperatures was estimated under a compound microscope at $10 \mathrm{x}$ magnification. Observations were also made at every $30 \mathrm{~min}$ interval. The time taken for $50 \%$ of the embryo and larva to reach each progressive stage was recorded (Fujisawa, 1993; Rahman et al., 2002). Development stage(s) were assessed for the first 50 embryos observed under a compound light microscope at 10x magnification. Embryos were scored as $\mathrm{Abn}=$ abnormal; $\mathrm{Deg}=$ degenerate; $1=$ fertilised eggs; $2=2$-cell stage; $4=4$-cell stage; $8=8$-cell stage; $16=$ equal to or more than 16 -cell; 32 = equal to or more than 32-cells; $\mathrm{B}=$ blastula; $\mathrm{G}=$ gastrula; $\mathrm{Pr}=$ prism; $2 \mathrm{P}=2$-arm pluteus; $4 \mathrm{P}=4$-arm pluteus.

\section{Survival}

An experiment to assess the survival of different larval stages (i.e., prism, 2-arm and 4-arm) was conducted in falcon tubes. The water bath was set at desired temperature levels $\left(22,25,28,31,34,37,40\right.$ and $\left.43^{\circ} \mathrm{C}\right)$. Approximately, 20-25 nos. of larvae were placed in each tube with $40 \mathrm{ml}$ FSW for $2 \mathrm{~h}$ at each experimental temperature. Larvae were cultured first at $28^{\circ} \mathrm{C}$ and transferred to different temperatures for $2 \mathrm{~h}$. At the end of the trial, each sample was examined under a dissecting microscope and the larvae were scored as swimming or dead. Larvae that were lying on the bottom of the container, but capable of swimming if distributed, were scored as being alive. Stages tested were: swimming blastula, gastrula, prism, 2-arm pluteus and 4-arm pluteus.

\section{Larval measurements}

Morphometric characteristics of larvae were checked at regular intervals and also measured and compared among the temperature treatments. Morphometric measurements taken were: larval length (LL), larval width (LW), body length (BL), post-oral arm (POA) and anterolateral arm length (ALA) (Fig. 2). All measurements

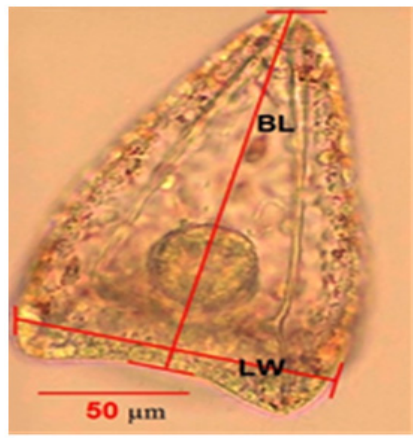

(a)

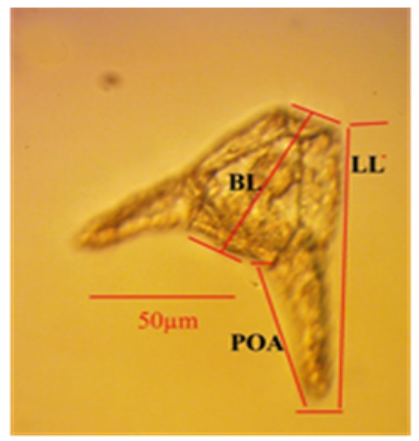

(b)

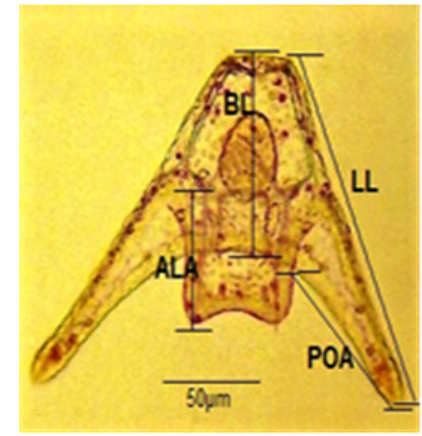

(c)

Fig. 2. Morphometric measurements of early larval stages of $T$. gratilla under Keyence digital microscope a) Prism. b) 2 arm pluteus and c) 4 arm pluteus stages. $\mathrm{LL}=$ larval length, $\mathrm{LW}=$ larval width, $\mathrm{BL}=$ body length, $\mathrm{POA}=$ post-oral arm length and $\mathrm{ALA}=$ antero-lateral arm length 
were made on freshly prepared specimens of larvae (within 1-2 h), following the techniques described previously by McEdward (1985) with some modifications. Larvae were fixed in $10 \%$ buffered formalin in FSW and then concentrated by allowing them to settle on the bottom of a watch glass. Subsequently, they were placed on microscope slides with a cover slip for final measurements and for taking photomicrographs under a compound microscope (Keyence VH-S30K).

\section{Data analysis}

Data were arcsine transformed before statistical analyses. All data collected from the fertilisation trials as well as larval development and growth trials were analysed by one-way analysis of variance (ANOVA), followed by Duncan's new range test (Duncan, 1955) using the statistical software "SPSS" version 20 and the significance level was set at 0.05 .

\section{Results}

\section{Hatching rate}

The hatching rate of $T$. gratilla embryos was found to be correlated with time at different experimental temperatures $\left(16-40^{\circ} \mathrm{C}\right)$ (Fig. 3). The maximum hatching rates were observed at 22 to $28^{\circ} \mathrm{C}$ where hatching times varied from 12 to $6 \mathrm{~h}$, respectively. However, the highest hatching success $(100 \%)$ was found with lower hatching duration at $28^{\circ} \mathrm{C}$.

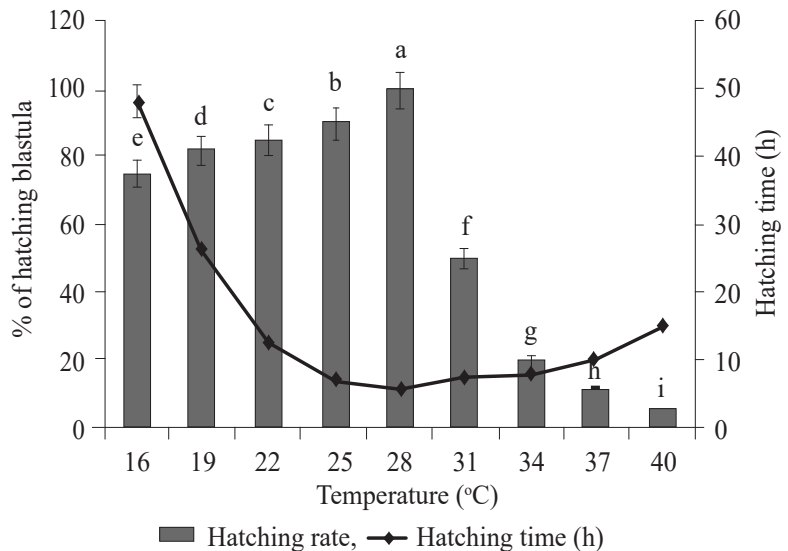

Fig. 3. Hatching time and percentage of hatching of $T$. gratilla embryos at different temperatures

\section{Incubation and early development}

The effects of different temperatures on embryonic and early larval development of $T$. gratilla are shown in Table $1 \mathrm{a}$ and b. At $16^{\circ} \mathrm{C}$, nearly 52.92 and $47.08 \%$ attained fertilised eggs and 2-cell stage respectively, whereas about $93.71 \%$ embryos reached 4 -cell stage at $8 \mathrm{~h}$ of incubation (Table 1a). On the other hand, 96\% embryos had touched the 16-cell stage in $12 \mathrm{~h}$ whereas 49.95 and $29 \%$ embryos reached blastula and 32-cell stage respectively at $24 \mathrm{~h}$ of incubation (Table 1a). It was also observed that $15.55 \%$ embryos degenerated during the same time of incubation. Nevertheless, $75.65 \%$ swimming and $20.5 \%$ abnormal

Table 1a. Effects of temperature $\left(16-22^{\circ} \mathrm{C}\right)$ on early development of $T$. gratilla. Data are expressed as $\%$ and denote mean values with five replicates

\begin{tabular}{|c|c|c|c|c|c|c|c|c|c|c|c|c|c|c|}
\hline \multirow{2}{*}{ Temp $\left({ }^{\circ} \mathrm{C}\right)$} & \multirow{2}{*}{ Time (h) } & \multirow{2}{*}{ Degen ${ }^{*}$} & \multirow{2}{*}{$\mathrm{Abn}^{* *}$} & \multicolumn{11}{|c|}{$\%$ of development stages } \\
\hline & & & & 1 & 2 & 4 & 8 & 16 & 32 & $\mathrm{~B}$ & $\mathrm{G}$ & $\operatorname{Pr}$ & $2 \mathrm{P}$ & $4 \mathrm{P}$ \\
\hline \multirow[t]{6}{*}{$\overline{16}$} & 4 & & & 52.92 & 47.08 & & & & & & & & & \\
\hline & 8 & & & & 6.29 & 93.71 & & & & & & & & \\
\hline & 12 & & & & & & 3.93 & 96.07 & & & & & & \\
\hline & 24 & 15.55 & & & & & & 5.5 & 29 & 49.95 & & & & \\
\hline & 48 & & $20.5(\mathrm{~B})$ & & & & & & 3.85 & 75.65 & & & & \\
\hline & 72 & & 49.53(B) & & & & & & & 50.47 & & & & \\
\hline \multirow[t]{6}{*}{19} & 4 & & & 43.26 & 41.42 & 11.85 & 3.47 & & & & & & & \\
\hline & 8 & & & & & & 11.18 & 88.82 & & & & & & \\
\hline & 12 & & & & & & & & 100 & & & & & \\
\hline & 24 & 18.47 & $2.05(\mathrm{~B})$ & & & & & & & 79.48 & & & & \\
\hline & 48 & & $15.53(\mathrm{Pr})$ & & & & & & & 9.75 & 36.65 & 38.08 & & \\
\hline & 72 & & $38.48(\mathrm{pl})$ & & & & & & & & & & 61.52 & \\
\hline \multirow[t]{6}{*}{22} & 4 & & & & 13.85 & 55.83 & 30.32 & & & & & & & \\
\hline & 8 & & & & & & & & 100 & & & & & \\
\hline & 12 & & & & & & & & & & 93.29 & 6.71 & & \\
\hline & 24 & 6.03 & & & & & & & & & 87.32 & 6.6 & & \\
\hline & 48 & & & & & & & & & & 41.88 & 6.9 & 51.21 & \\
\hline & 72 & & & & & & & & & & & 14.88 & 85.12 & \\
\hline
\end{tabular}

Embryos were scored as Abn = abnormal; Deg = degenerate; $1=$ fertilised eggs; $2=2$-cell stage; $4=4$-cell stage; $8=8$-cell stage; $16=\geq 16$ cells; $32=\geq 32$ cells; $\mathrm{B}=$ blastula; $\mathrm{G}=$ gastrula; $\mathrm{Pr}=$ prism; $2 \mathrm{P}=2$-arm pluteus; $4 \mathrm{P}=4$-arm pluteus 
blastula were observed at $48 \mathrm{~h}$ incubation. However, 100\% embryos attained the blastula stage in which $50.47 \%$ were swimming and $49.53 \%$ were abnormal at $72 \mathrm{~h}$ of incubation (Table 1a).

At $19^{\circ} \mathrm{C}$, nearly about 43.26 and $41.42 \%$ embryos attained the fertilised eggs stage, and 2-cellstage respectively at $4 \mathrm{~h}$ incubation, whereas $100 \%$ embryos were found to be at 32-cell stage at $12 \mathrm{~h}$ of incubation. On the other hand, around 88.82 and $79.48 \%$ embryos were observed at 16-cell and swimming blastula stages at 8 and $24 \mathrm{~h}$ incubation respectively (Table 1a), whereas some larvae appeared to show abnormal $(2.05 \%)$ growth of cells in the blastocoels and also $18.47 \%$ were found degenerated. At $48 \mathrm{~h}$ of incubation, nearly $84.72 \%$ embryos had reached gastrula stage whereas about $15.28 \%$ were still in prism stage and were observed to be abnormal. About $61.52 \%$ embryos at 2-arm pluteus stage were found to be swimming, whereas $38.48 \%$ of 2 -arm pluteus stage were found in abnormal condition (Table 1a).

At $22^{\circ} \mathrm{C}$, nearly about $55.83 \%$ embryos reached 4 -cell stage in $4 \mathrm{~h}$ of incubation, followed by 30.32 and $13.85 \%$ embryos reached 8-cell and 2-cell stages respectively, whereas $100 \%$ embryos were found at 32-cell stage at $8 \mathrm{~h}$ of incubation (Table 1a). It was also observed that $93.29 \%$ embryos reached gastrula stage at $12 \mathrm{~h}$ incubation, whereas, $87.32 \%$ embryos attained the same stage at $24 \mathrm{~h}$ of incubation. About $6.03 \%$ embryos were found degenerated. At $48 \mathrm{~h}$ of incubation, 51.21 and $41.88 \%$ embryos were found at 2-arm and gastrula stage respectively whereas $6.9 \%$ were found at prism stage. At $72 \mathrm{~h}$ of incubation, $85.12 \%$ embryos were at 2-arm stage whereas, $14.88 \%$ were at prism stage (Table 1a).

In $4 \mathrm{~h}$ incubation at $25^{\circ} \mathrm{C}, 100 \%$ embryos reached 32-cell stage, whereas nearly about $95.25 \%$ embryos reached swimming blastula stage. In addition, it was also observed that 65.67 and $34.33 \%$ embryos had extended swimming blastula and gastrula stages respectively at $12 \mathrm{~h}$ of incubation whereas $94.48,94.26$ and $100 \%$ embryos reached prism, 2-arm pluteus and 4-arm pluteus stages at 24; 48 and $72 \mathrm{~h}$ of incubation respectively (Table $1 \mathrm{~b}$ ).

At $28^{\circ} \mathrm{C}$ in $4 ; 8$ and $12 \mathrm{~h}$ incubation, $100 \%$ embryos reached 16-cell, 32-cell and blastula stages respectively whereas, 94.3 and $94.67 \%$ embryos reached prism and 4-arm pluteus stages in 24 and $48 \mathrm{~h}$ incubation respectively (Table 1b).

At $31^{\circ} \mathrm{C}, 96.5 \%$, embryos attained 32-cell stage in $8 \mathrm{~h}$ of incubation. On the other hand, nearly about 94.7 and $49.18 \%$ embryos attained swimming blastula stage in 8 and $12 \mathrm{~h}$ of incubation respectively, while $50.82 \%$ embryos reached gastrula stage in $12 \mathrm{~h}$ incubation. In $24 \mathrm{~h}$ incubation, 88.85 and $11.15 \%$ embryos attained

Table $1 \mathrm{~b}$. Effects of temperature $\left(25-31^{\circ} \mathrm{C}\right)$ on early development of $T$. gratilla. Data are presented as $\%$ and denote mean values with five replicates

\begin{tabular}{|c|c|c|c|c|c|c|c|c|c|c|c|c|c|c|}
\hline \multirow{2}{*}{ Temperature $\left({ }^{\circ} \mathrm{C}\right)$} & \multirow{2}{*}{ Time (h) } & \multirow{2}{*}{ Deg. ${ }^{*}$} & \multirow{2}{*}{$\mathrm{Abn}^{* *}$} & \multicolumn{11}{|c|}{$\%$ of development stages } \\
\hline & & & & 1 & 2 & 4 & 8 & 16 & 32 & B & G & $\operatorname{Pr}$ & $2 \mathrm{P}$ & $4 \mathrm{P}$ \\
\hline \multirow[t]{6}{*}{25} & 4 & & & & & & & 100 & & & & & & \\
\hline & 8 & & & & & & & 4.75 & 95.25 & & & & & \\
\hline & 12 & & & & & & & & 65.67 & 34.33 & & & & \\
\hline & 24 & 3.73 & 0.42 & & & & & & & & 2.12 & 93.88 & & \\
\hline & 48 & 2.17 & 0.65 & & & & & & & & & & 12.38 & 84.8 \\
\hline & 72 & & & & & & & & & & & & 100 & \\
\hline \multirow[t]{6}{*}{28} & 4 & & & & & & & 100 & & & & & & \\
\hline & 8 & & & & & & & & 100 & & & & & \\
\hline & 12 & & & & & & & & & 100 & & & & \\
\hline & 24 & 5.65 & & & & & & & & & 5.7 & 88.65 & & \\
\hline & 48 & 0.8 & & & & & & & & & & & 5.83 & 93.37 \\
\hline & 72 & & & & & & & & & & & & 100 & \\
\hline \multirow[t]{6}{*}{31} & 4 & & & & & & & 3.5 & 96.5 & & & & & \\
\hline & 8 & & & & & & & & 5.3 & 94.7 & & & & \\
\hline & 12 & 5.04 & & & & & & & & 49.18 & 45.78 & & & \\
\hline & 24 & 42.88 & $12.43(\mathrm{Pr})$ & & & & & & & & & 44.69 & & \\
\hline & 48 & 100 & & & & & & & & & & & & \\
\hline & 72 & 100 & & & & & & & & & & & & \\
\hline
\end{tabular}

Embryos were scored as Abn $=$ abnormal; Deg $=$ degenerate; $1=$ fertilised eggs; $2=2$-cell stage; $4=4$-cell stage; $8=8$-cell stage; $16=\geq 16$ cells; $32=\geq 32$ cells; $\mathrm{B}=$ blastula; $\mathrm{G}=$ gastrula; $\mathrm{Pr}=$ prism; $2 \mathrm{P}=2$ arm pluteus; $4 \mathrm{P}=4$ arm pluteus 
2-arm pluteus and prism stages respectively whereas, 66.58 and $33.42 \%$ embryos attained 4 -arm and 2-arm pluteus stages in $48 \mathrm{~h}$ incubation respectively. However, at this temperature, embryos terminated to develop further from 2-arm pluteus stage (Table 1b).

\section{Effects of temperature on the duration of development}

The effects of different temperatures on development time of $T$. gratilla are summarised in Table 2. The 2-cell stage occurred within $5.28 \pm 0.02,3.10 \pm 0.05$ and $2.46 \pm 0.04 \mathrm{~h}$ after fertilisation at 16,19 and $22^{\circ} \mathrm{C}$, respectively. When seawater temperatures were set at 25 and $28^{\circ} \mathrm{C}$, the 2-cell stage reached at $1.38 \pm 0.02$ and $1.22 \pm 0.01 \mathrm{~h}$, whereas the hatching blastula developed within $10.69 \pm 0.09$ and $7.81 \pm 0.08 \mathrm{~h}$ after incubation, respectively (Table 2 ). At $34^{\circ} \mathrm{C}$, embryos attained the swimming blastula stage but showed abnormal growth after $7 \mathrm{~h}$ post-incubation (data not shown). At $31^{\circ} \mathrm{C}$, the developmental time of 2-cell up to 4-arm pluteus stage was comparatively shorter than those of other temperatures (Table 2). On the other hand, the survival (\%) of larvae at prism, 2-arm and 4-arm stages were observed to be dissimilar at different temperatures $\left(22\right.$ to $\left.34^{\circ} \mathrm{C}\right)$, but the highest values $(100 \%$ or near $100 \%$ ) were always found at 25 and $28^{\circ} \mathrm{C}$ (Fig. 4).

Development times of 2, 4, 8 and 16-cell stages showed significant differences $(p<0.05)$ among all the temperature levels tested. The development time of 2-cell stage decreased with increasing temperature (Table 2) and within the temperature range between 25 and $28^{\circ} \mathrm{C}$, the required time was found to be almost similar. However, the development time of 2-cell stage decreased when temperature was set at $>28^{\circ} \mathrm{C}$. The hatching time decreased sharply from 16 to $22^{\circ} \mathrm{C}$, but was nearly constant at higher temperatures $\left(25-34^{\circ} \mathrm{C}\right)$. The developmental times from

Table 2. Time $(\mathrm{h})(\mathrm{Mean} \pm \mathrm{SD} ; \mathrm{n}=10)$ taken by $50 \%$ of $T$. gratilla embryos to reach different developmental stages at different temperatures

\begin{tabular}{|c|c|c|c|c|c|c|c|c|c|}
\hline \multirow{2}{*}{ Temperature $\left({ }^{\circ} \mathrm{C}\right)$} & \multicolumn{9}{|c|}{ Duration (h) of cell developmental stages } \\
\hline & 2-cell & 4-cell & 8-cell & 16-cell & Blastula & Gastrula & Prism & 2-arm & 4-arm \\
\hline 16 & $\begin{array}{l}5.28 \pm 0.02^{\mathrm{a}} \\
(5.26-5.32)\end{array}$ & $\begin{array}{l}7.07 \pm 0.02^{\mathrm{a}} \\
(7.03-7.09)\end{array}$ & $\begin{array}{l}8.40 \pm 0.01^{\mathrm{a}} \\
(8.38-8.42)\end{array}$ & $\begin{array}{l}9.93 \pm 0.04^{\mathrm{a}} \\
(9.88-9.99)\end{array}$ & $\begin{array}{l}48.87 \pm 0.09^{\mathrm{a}} \\
(48.68-48.99)\end{array}$ & $*$ & - & - & - \\
\hline 19 & $\begin{array}{l}3.10 \pm 0.05^{b} \\
(3.05-3.18)\end{array}$ & $\begin{array}{l}5.11 \pm 0.02^{\mathrm{b}} \\
(5.09-5.14)\end{array}$ & $\begin{array}{l}5.93 \pm 0.09^{b} \\
(5.78-6.03)\end{array}$ & $\begin{array}{l}5.95 \pm 0.06^{\mathrm{b}} \\
(5.87-6.04)\end{array}$ & $\begin{array}{l}23.86 \pm 0.08^{\mathrm{a}} \\
(23.68-23.96)\end{array}$ & $\begin{array}{l}37.58 \pm 0.08^{\mathrm{a}} \\
(37.48-37.76)\end{array}$ & $\begin{array}{l}51.97 \pm 0.08^{\mathrm{a}} \\
(51.88-52.11)\end{array}$ & $\begin{array}{l}71.51 \pm 0.05^{\mathrm{a}} \\
(71.43-71.58)\end{array}$ & $*$ \\
\hline 22 & $\begin{array}{l}2.46 \pm 0.04^{c} \\
2.39-2.50)\end{array}$ & $\begin{array}{l}4.30 \pm 0.04^{c} \\
(4.25-4.38)\end{array}$ & $\begin{array}{l}4.91 \pm 0.08^{c} \\
(4.78-5.03)\end{array}$ & $\begin{array}{l}4.88 \pm 0.07^{c} \\
(4.77-4.98)\end{array}$ & $\begin{array}{l}11.80 \pm 0.09^{c} \\
(11.67-11.98)\end{array}$ & $\begin{array}{l}21.75 \pm 08^{\mathrm{b}} \\
(21.65-21.87)\end{array}$ & $\begin{array}{l}27.83 \pm 0.08^{b} \\
27.65-27.91)\end{array}$ & $\begin{array}{l}47.10 \pm 0.06^{\mathrm{b}} \\
(47.01-47.20)\end{array}$ & $\begin{array}{l}71.04 \pm 0.08^{\mathrm{a}} \\
(79.89-71.12)\end{array}$ \\
\hline 25 & $\begin{array}{l}1.38 \pm 0.02^{\mathrm{d}} \\
(1.35-1.41)\end{array}$ & $\begin{array}{l}2.36 \pm 0.08^{d} \\
(2.23-2.45)\end{array}$ & $\begin{array}{l}2.84 \pm 0.08^{\mathrm{d}} \\
(2.68-2.89)\end{array}$ & $\begin{array}{l}3.19 \pm 0.08^{\mathrm{d}} \\
(3.08-3.36)\end{array}$ & $\begin{array}{l}10.69 \pm 0.09^{\mathrm{d}} \\
(7.64-7.89)\end{array}$ & $\begin{array}{l}18.81 \pm 0.07^{\circ} \\
(18.68-18.89)\end{array}$ & $\begin{array}{l}24.25 \pm 0.04^{c} \\
(24.18-24.31)\end{array}$ & $\begin{array}{l}34.88 \pm 0.04^{c} \\
(34.80-34.95)\end{array}$ & $\begin{array}{l}48.02 \pm 0.10^{\mathrm{a}} \\
(47.85-48.2)\end{array}$ \\
\hline 28 & $\begin{array}{l}1.22 \pm 0.01^{\mathrm{e}} \\
(1.21-1.24)\end{array}$ & $\begin{array}{l}2.09 \pm 0.02^{\mathrm{e}} \\
(2.06-2.11)\end{array}$ & $\begin{array}{l}2.76 \pm 0.10^{\mathrm{e}} \\
(2.65-2.92)\end{array}$ & $\begin{array}{l}2.90 \pm 0.07^{\mathrm{e}} \\
(2.77-2.99)\end{array}$ & $\begin{array}{l}7.81 \pm 0.08^{e} \\
(7.64-7.89)\end{array}$ & $\begin{array}{l}14.58 \pm 0.05^{\mathrm{d}} \\
(14.48-14.65)\end{array}$ & $\begin{array}{l}22.25 \pm 0.06^{d} \\
22.18-22.35)\end{array}$ & $\begin{array}{l}33.01 \pm 0.07^{\mathrm{d}} \\
(32.88-33.11)\end{array}$ & $\begin{array}{l}45.22 \pm 0.05^{\mathrm{c}} \\
(45.12-45.30)\end{array}$ \\
\hline 31 & $\begin{array}{l}1.08 \pm 0.03^{\mathrm{f}} \\
(1.01-1.11)\end{array}$ & $\begin{array}{l}1.94 \pm 0.04^{f} \\
(1.89-1.99)\end{array}$ & $\begin{array}{l}2.40 \pm 0.02^{f} \\
(2.38-2.43)\end{array}$ & $\begin{array}{l}2.80 \pm 0.09^{\mathrm{f}} \\
2.67-2.98)\end{array}$ & $\begin{array}{l}7.67 \pm 0.11^{\text {ef }} \\
(7.52-7.86)\end{array}$ & $\begin{array}{l}12.05 \pm 0.06^{\mathrm{e}} \\
(11.95-12.15)\end{array}$ & $\begin{array}{l}16.91 \pm 0.06^{\mathrm{e}} \\
(16.78-16.98)\end{array}$ & $\begin{array}{l}26.02 \pm 0.09^{\mathrm{e}} \\
(25.89-26.13)\end{array}$ & $\begin{array}{l}41.28 \pm 0.05^{\mathrm{d}} \\
(41.17-41.33)\end{array}$ \\
\hline 34 & $\begin{array}{l}1.01 \pm 0.05^{\mathrm{d}} \\
(0.96-1.11)\end{array}$ & $\begin{array}{l}1.82 \pm 0.03^{\mathrm{g}} \\
(1.78-1.87)\end{array}$ & $\begin{array}{l}2.84 \pm 0.21^{g} \\
(2.35-2.89)\end{array}$ & $\begin{array}{l}2.61 \pm 0.08^{\mathrm{g}} \\
(2.48-2.76)\end{array}$ & $*$ & - & - & - & - \\
\hline
\end{tabular}

"All larvae showed abnormal development; Desired larval stage was not found and all died

Mean values in the same column with the same superscripts are not significantly different $(\mathrm{p}>0.05)$

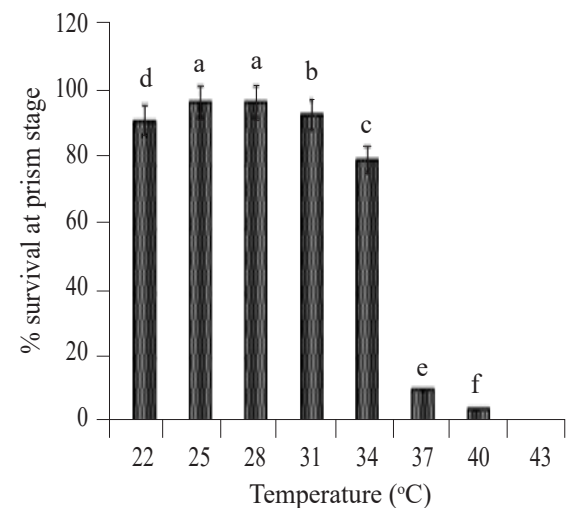

(a)

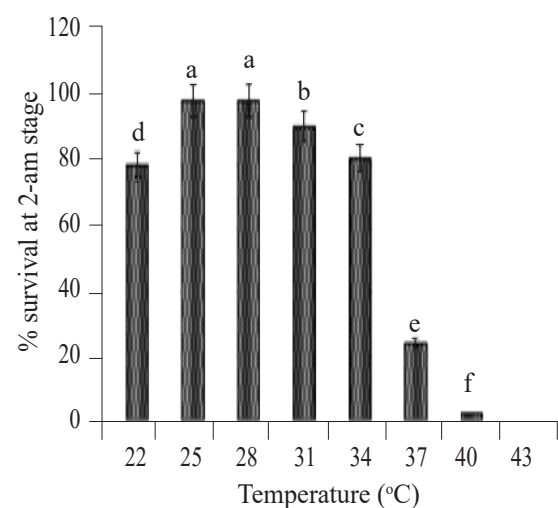

(b)

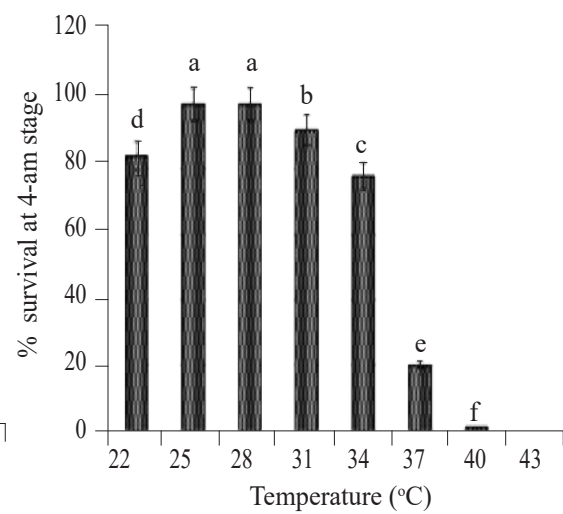

(c)

Fig. 4. Percentage survival of (a) prism, (b) 2-arm, (c) 4-arm pluteus stages of T. gratilla at different temperatures 
early gastrula to 4-arm pluteus stages among all temperature treatments differed significantly $(\mathrm{p}<0.05)$.

\section{Larval growth and survival}

Impact of temperature on early larval growth are presented in Table 3, 4 and 5. Only four temperature levels, viz., 22, 25, 28 and $31^{\circ} \mathrm{C}$, had development from 2-cell until 4-arm pluteus (Table 1). The morphometric differences of prism larvae at different temperature treatments were also investigated (Table 3). The highest larval length (LL) of $121.96 \pm 0.70 \mu \mathrm{m}$ and larval width (LW) of $113.99 \pm 0.55$ $\mu \mathrm{m}$ in prism stage were found at $28^{\circ} \mathrm{C}$ whereas, the lowest values of LL $(91.48 \pm 0.05 \mu \mathrm{m})$ and $\mathrm{WL}(89.27 \pm 0.51 \mu \mathrm{m})$ were found at $22^{\circ} \mathrm{C}$. The size of the larvae increased with increasing temperature from 22 to $28^{\circ} \mathrm{C}$ but reduced at $31^{\circ} \mathrm{C}$. However, length and width of larvae differed significantly $(p<0.05)$ among the 4 temperature levels examined. Morphometric differences of 2-arm pluteus larvae at different temperature treatments were also investigated (Table 4). In this stage, larvae attained maximum values for larval length (LL) $(206.87 \pm 0.52 \mu \mathrm{m})$, body length
(BL) $(131.82 \pm 0.49 \mu \mathrm{m})$ and post-oral arm length (POA) $(86.61 \pm 0.30 \mu \mathrm{m})$ at $28^{\circ} \mathrm{C}$, whereas the minimum values for larval length $(153.64 \pm 0.56 \mu \mathrm{m})$, body length (96. $28 \pm 0.37 \mu \mathrm{m})$ and post-oral arm length $(59.05 \pm 0.356 \mu \mathrm{m})$ were observed at $22^{\circ} \mathrm{C}$. However, body length and post-oral arm length among the four temperature treatments were significantly different $(\mathrm{p}<0.05)$. Comparisons among the four morphometric characteristics in 4-arm pluteus larvae of $T$. gratilla at different temperature levels are presented in Table 5. The results demonstrated that the 4-arm pluteus larva attained the highest larval, body, post-oral and anterior oral arm length of $250.42 \pm 0.60,175.31 \pm 0.46,133.32 \pm 0.47$ and $92.35 \pm 0.34 \mu \mathrm{m}$ at $28^{\circ} \mathrm{C}$, while the lowest values of $186.09 \pm 0.46,123.28 \pm 0.45,68.03 \pm 0.30$ and $40.50 \pm 0.48 \mu \mathrm{m}$, respectively were found at $22^{\circ} \mathrm{C}$. However, similar to the 2-arm pluteus larvae, the morphometric measurements of 4-arm pluteus larvae in all temperature treatments differed significantly $(\mathrm{p}<0.05)$.

The survival (\%) of larvae at prism, 2-arm and 4-arm stages were observed to be dissimilar at different

Table 3. Comparisons of two morphometric characters of the larvae of T. gratilla at prism stage under different temperature treatments. A total of 45 larvae were measured for each replicate in each treatment. All values represent mean $\pm \mathrm{SE}$

\begin{tabular}{lll}
\hline \multirow{2}{*}{ Temperature $\left({ }^{\circ} \mathrm{C}\right)$} & \multicolumn{2}{c}{ Measurement of morphometric characteristics $(\mu \mathrm{m})$} \\
\cline { 2 - 3 } & Larval length $(\mathrm{LL})$ & Larval width $(\mathrm{LW})$ \\
\hline 22 & $91.48 \pm 0.50^{\mathrm{a}}(85.44-99.54)$ & $89.29 \pm 0.51^{\mathrm{a}}(83.86-97.85)$ \\
25 & $100.59 \pm 0.66^{\mathrm{b}}(95.39-105.16)$ & $95.19 \pm 0.47^{\mathrm{a}}(91.17-98.85)$ \\
28 & $121.96 \pm 0.70^{\mathrm{d}}(116.34-127.55)$ & $113.99 \pm 0.55^{\mathrm{d}}(102.58-119.98)$ \\
31 & $113.62 \pm 0.96^{\mathrm{c}}(116.34-127.55)$ & $110.36 \pm 4.74^{\mathrm{c}}(101.85-119.36)$ \\
\hline
\end{tabular}

Mean values in the same column with the same superscripts are not significantly different $(\mathrm{p}>0.05)$

Table 4. Comparisons of three morphometric characters of the larvae of T. gratilla at 2-arm stage under different temperature treatments. A total of 45 larvae were measured for each replicate in each treatment. All values represent mean $\pm \mathrm{SE}$

\begin{tabular}{llll}
\hline \multirow{2}{*}{ Temperature $\left({ }^{\circ} \mathrm{C}\right)$} & \multicolumn{3}{c}{ Measurement of morphometric characteristics $(\mu \mathrm{m})$} \\
\cline { 2 - 4 } & Larval length $(\mathrm{LL})$ & Post-oral arm length $(\mathrm{POA})$ & Body length $(\mathrm{BL})$ \\
\hline 22 & $153.64 \pm 0.56^{\mathrm{a}}(145.37-164.10)$ & $59.05 \pm 0.36^{\mathrm{a}}(53.67-62.08)$ & $96.82 \pm 0.37^{\mathrm{a}}(92.82-102.24)$ \\
25 & $168.99 \pm 0.53^{\mathrm{b}}(164.45-178.38)$ & $63.66 \pm 0.41^{\mathrm{a}}(58.50-69.68)$ & $110.82 \pm 0.50^{\mathrm{b}}(104.96-116.67)$ \\
28 & $206.87 \pm 0.52^{\mathrm{d}}(199.96-210.89)$ & $86.61 \pm 0.30^{\mathrm{d}}(80.57-90.48)$ & $131.82 \pm 0.49^{\mathrm{d}}(126.02-139.27)$ \\
31 & $177.17 \pm 2.98^{\mathrm{c}}(146.37-210.42)$ & $73.88 \pm 0.37^{\mathrm{c}}(69.15-76.68)$ & $121.40 \pm 1.79^{\mathrm{c}}(92.68-133.72)$ \\
\hline
\end{tabular}

Mean values in the same column with the same superscripts are not significantly different $(\mathrm{p}>0.05)$

Table 5. Comparisons of four morphometric characters of the larvae of T. gratilla at 4-arm stage under different temperature treatments. A total of 45 larvae were measured for each replicate in each treatment. All values represent mean $\pm \mathrm{SE}$

\begin{tabular}{lllll}
\hline \multirow{2}{*}{ Temperature $\left({ }^{\circ} \mathrm{C}\right)$} & \multicolumn{3}{c}{ Measurement of morphometric characteristics $(\mu \mathrm{m})$} \\
\cline { 2 - 5 } & Larval length $(\mathrm{LL})$ & Post oral arm $(\mathrm{POA})$ & Body length $(\mathrm{BL})$ & Anterior lateral arm $($ ALA) \\
\hline 22 & $186.09 \pm 0.46^{\mathrm{a}}(180.04-189.85)$ & $68.03 \pm 0.30^{\mathrm{a}}(63.84-70.96)$ & $123.28 \pm 0.45^{\mathrm{a}}(118.27-128.32)$ & $40.50 \pm 0.48^{\mathrm{a}}(35.40-45.95)$ \\
25 & $197.99 \pm 0.40^{\mathrm{b}}(192.68-202.72)$ & $75.25 \pm 0.40^{\mathrm{b}}(70.44-79.88)$ & $134.96 \pm 0.61^{\mathrm{b}}(127.78-139.86)$ & $53.30 \pm 0.26^{\mathrm{b}}(50.44-55.98)$ \\
28 & $250.42 \pm 0.60^{\mathrm{d}}(244.27-256.38)$ & $133.32 \pm 0.47^{\mathrm{d}}(129.83-139.85)$ & $175.31 \pm 0.46^{\mathrm{d}}(169.98-179.02)$ & $92.35 \pm 0.34^{\mathrm{d}}(87.16-95.76)$ \\
31 & $238.51 \pm 0.49^{\mathrm{c}}(232.55-244.25)$ & $120.47 \pm 0.47^{\mathrm{c}}(115.48-125.88)$ & $147.48 \pm 2.26^{\mathrm{c}}(117.82-77.58)$ & $83.17 \pm 0.46^{\mathrm{c}}(87.64-87.83)$ \\
\hline
\end{tabular}

Mean values in the same column with the same superscripts are not significantly different $(\mathrm{p}>0.05)$ 
experimental temperatures $\left(22\right.$ to $\left.34^{\circ} \mathrm{C}\right)$, but the highest values $(100 \%$ or near $100 \%)$ were always found at 25 and $28^{\circ} \mathrm{C}$ (Fig. 4).

\section{Discussion}

Critical limits of temperature on several sea urchin species have been experimented to assess the best temperature for optimum development and growth of embryo and larvae. Some studies concluded that temperature is one of the most limiting factors among the abiotic parameters that have influence on earliest stages of development such as fertilised eggs, zygotes and cleavage (Andronikov, 1975; Bressan et al., 1995; Swewell and Young, 1999; Sarifudin et al., 2016). Fujisawa and Shigei (1990) reported that temperature dependence is not universal but rather species specific, especially in early larval development stages. Nevertheless, our experiment represents the first-time investigation concerning the effects of various temperature levels on embryonic and larval development in short-spined collector sea urchin, T. gratilla. Results obtained from the present experiment revealed that embryos survived and developed through fertilisation within the temperature range from 19 to $31^{\circ} \mathrm{C}$. However, at temperatures lower than $19^{\circ} \mathrm{C}$ or higher than $31^{\circ} \mathrm{C}$, the embryos developed upto the swimming blastula stage and then became abnormal and ultimately died. At $19^{\circ} \mathrm{C}$, the development of embryo continued until 2-arm pluteus stage but the larvae grew abnormally and died eventually. According to Andronikov (1975), environmental temperature is not only a limiting factor primarily in the earliest stages of development (from eggs to cleavage stages) but also in the distribution of a species. Therefore, the embryos and larvae will die if fertilisation takes place at temperatures beyond the limit for normal development. The results of our study demonstrated that $28^{\circ} \mathrm{C}$ was the best temperature in respect of highest growth, development and survival of larvae of $T$. gratilla compared to other temperature treatments tested. It can be explained that the maximum temperature limit for normal development is only $1-3^{\circ} \mathrm{C}$ higher than the temperatures encountered in the natural conditions (Andronikov, 1975; Sarifudin et al., 2016). Slowest development occurred at $16^{\circ} \mathrm{C}$, which was also observed in other sea urchin species (Sewell and Young, 1999; Rahman et al., 2007; Sarifudin et al., 2016). The findings of our study were also the same as Rahman et al. (2007), who found abnormality in the early development and larval growth of sea urchin (Echinometra mathaei) beyond the low $\left(16^{\circ} \mathrm{C}\right)$ and high temperature $\left(34^{\circ} \mathrm{C}\right)$ levels. Similar results were also observed in other temperate and tropical species of Indo-Pacific sea urchins (Matsumoto et al., 1988; Fujisawa, 1993; Sarifudin et al., 2016).
Morphometric characteristics for prism larvae did not differ significantly among the temperature levels investigated. In our study, the highest length and width of larvae for prism, 2 and 4-arm pluteus stages were observed at $28^{\circ} \mathrm{C}$. The lowest values of length and width were obtained at $22^{\circ} \mathrm{C}$ for prism until 4 -arm pluteus stage. According to Rupp (1973) and Sarifudin et al. (2016), normal larval development of tropical sea urchins occurred only below $34^{\circ} \mathrm{C}$. The synchronised development of larvae is another point to be considered in the effect of temperature on the mode of development. Fig. 2 clearly shows that embryos of $T$. gratilla developed synchronously in the temperature range from 19 to $28^{\circ} \mathrm{C}$ and asynchronously after $31^{\circ} \mathrm{C}$. Most of the larvae were physically normal at this tested temperature $\left(31^{\circ} \mathrm{C}\right)$, indicating a range of temperature tolerance of this species. Fujisawa (1989) and Rahman et al. (2007) stated that the tolerance characteristics of embryos and larvae could determine the distribution of sea urchins.

The average annual seawater temperature in Malaysia ranged between 27 to $31^{\circ} \mathrm{C}$ (Sarifudin et al., 2016). The developmental speed of $T$. gratilla varies with the above seawater temperature fluctuations and also becomes lethal when the temperature is extremely low or high. Our study revealed that lowering the temperature decreases the embryonic and early larval developmental speed and vice-versa when temperature increases. Extreme low and high temperature $\left(16\right.$ and $\left.34^{\circ} \mathrm{C}\right)$ causes death of embryos after hatching. Similar results were also obtained in other tropical species of sea urchin, Echinometra mathaei and D. setosum (Rahman et al., 2007; Sarifudin et al., 2016).

To the best of our knowledge, this is the first study to investigate the influence of temperature variations on embryonic and early larval development and morphometric characteristics in the short-spined collector sea urchin, T. gratilla. The findings of the present study would not only be helpful to understand the critical limits of temperature but also to find out the appropriate temperature levels for the optimum growth and development of embryo and larvae. This would eventually lead towards the development of breeding and larval rearing techniques for the high valued $T$. gratilla for seed production, stock enhancement and commercial aquaculture.

\section{Acknowledgements}

We would like to extend our grateful thanks to Ministry of Science, Technology and Innovation (MOSTI), Malaysia for providing financial supports through the Research Management Centre (RMC) of Universiti Putra Malaysia (UPM) under the "Science Fund" grant vide Project No. 04-01-04-SF2227 for undertaking this research successfully. 


\section{References}

Andronikov, V. B. 1975. Heat resistance of gametes of marine invertebrates in relation to temperature conditions under which the species exist. Mar. Biol., 30: 1-12.

Bressan, M., Marin, M. and Brunetti, R. 1995. Influence of temperature and salinity on embryonic development of Paracentrotus lividus (Lmk, 1816). Hydrobiologia, 304: 175-184.

Britton, G., Liaaen-Jensen, S. and Pfander, H. 2004. Carotenoids handbook. Birkhauser Verlag, Boston, USA.

Byrne, M. 2010. Impact of climate change stressors on marine invertebrate life histories with a focus on the Mollusca and Echinodermata. In: Yuzhu, Y. (Ed.), Climate alert: Climate change monitoring and strategy. University of Sydney Press, Sydney, p.142-185.

Byrne, M. 2012. Global change ecotoxicology: identification of early life history bottlenecks in marine invertebrates, variable species responses and variable experimental approaches. Mar. Environ. Res., 76: 3-15.

Byrne, M., Soars, N. A., Selvakumaraswamy, P., Dworjanyn, S. A. and Davis, A. R. 2010. Sea urchin fertilisation in warm, acidified and high $\mathrm{pCO}_{2}$ ocean across a range of sperm densities. Mar. Environ. Res., 69: 234-239.

Byrne, M., Selvakumaraswamy, P., Ho, M. A., Woolsey, E. and Nguyen, H. D. 2011. Sea urchin development in a global change hot spot, potential for southerly migration of thermotolerant propagules. Deep Sea Research Part II, Topical Studies in Oceanography, 58(5), 712-719. DOI10.1016/j. dsr2.2010.06.010.

Dinnel, P. A., Link, J. M., Stober, Q. J., Letourneau, M. W. and Roberts, W. E. 1989. Comparative sensitivity of sea urchin sperm bioassays to metals and pesticides. Arch. Environ. Contam. Toxicol., 18: 748-755.

Dincer, T. and Cakli, S. 2007. Chemical composition and biometrical measurements of the Turkish Sea urchin (Paracentrotus lividus, Lamarck, 1816). Criti. Rev. Food Sci. Nutr., 47(1): 21-26.

Duncan, D. B. 1955. Multiple range and multiple F tests. Biometrics, 11: $1-42$

Dworjanyn, S. A., Pirozzi, I. and Liu, W. 2007. The effect of additional algae feeding stimulants to artificial diets for the sea urchin Tripneustes gratilla. Aquaculture, 273: 624-633.

Figueira, W. F. and Booth, D. J. 2010. Increasing ocean temperatures allow tropical fishes to survive overwinter in temperate waters. Global Change Biol., 16: 506-516.

Fujisawa, H. 1989. Differences in temperature dependence of early development of sea urchins with different growing seasons. Biol. Bull., 176: 96-102.

Fujisawa, H. 1993. Temperature sensitivity of a hybrid between two species of sea urchins differing in thermo-tolerance. Develop. Growth Differ., 35: 395-401.
Fujisawa, H. and Shigei, M. 1990. Correlation of embryonic temperature sensitivity of sea urchins with spawning season. J. Exp. Mar. Biol. Ecol., 136: 123-139.

Gambaiani, D. D., Mayol, P., Isaac, S. J. and Simmonds, M. P 2009. Potential impacts of climate change and greenhouse gas emissions on Mediterranean marine ecosystems and cetaceans. J. Mar. Biol. Ass. U. K., 89: 179-201.

Graham, C. T. and Harrod, C. 2009. Implications of climate change for the fishes of the British Isles. J. Fish Biol., 74: 1143-1205.

Hart, M. W. 2002. Life history evolution and comparative developmental biology of echinoderms. Evol. Dev., 4: 62-71.

IPCC 2007. The fourth assessment report of the IPCC. International Panel on Climate Change. Cambridge University Press, Cambridge, UK.

Johnson, C. R., Banks, S. C., Barrett, N. S., Cazassus, F., Dunstan, P. K., Edgar, G. J., Frusher, S. D., Gardner, C., Haddon, M., Helidoniotis, F., Hill, K. L., Holbrook, N. J., Hosie, G. W., Last, P. R., Ling, S. D., Melbourne-Thomas, J., Miller, K., Pecl, G. T., Richardson, A. J., Ridgway, K. R., Rintoul, S. R., Ritz, D. A., Ross, D. J., Sanderson, J. C., Shepherd, S. A., Slotwinski, A., Swadling, K. M. and Taw, N. 2011. Climate change cascades: Shifts in oceanography, species' ranges and subtidal marine community dynamics in eastern Tasmania. $J$. Exp. Mar. Biol. Ecol., 400: 17-32.

Juinio-Menez, M. A., Macawaris, N. and Bangi, H. 1998. Community-based sea urchin (Tripneustes gratilla) grow-out culture as a resource management tool. Can. Spec. Pub. Fish. Aquatics, 125: 393-399.

Lawrence, J. M. and Agatsuma, Y. 2001a. The ecology of Tripneustes. In: Lawrence, J. M. (Ed.), Edible sea urchins: biology and ecology. Elsevier Science, Amsterdam, p. 395-341.

Lawrence, J. M., Lawrence, A. L., McBride, S. C., George, S. B., Watts, S. A. and Plank, L. R. 2001b. Developments in the use of prepared feeds in sea-urchin aquaculture. World Aquacult., 32(3): 34-39.

Lawrence, J. M. 2007. Edible sea urchins: biology and ecology. Elsevier Science, Amsterdam, p. 499-520.

Matsumoto, Y., Kominami, T. and Ishikawa, M. 1988. Timers in early development of sea urchin embryos. Develop. Growth Differ., 30: 543-552.

McEdward, L. R. 1985. Effects of temperature on the body form, growth, electron transport system activity and development rate of an echinopluteus. J. Exp. Mar. Biol. Ecol., 93: 169-181.

Mita, M., Hino A. and Yasumasu, I. 1984. Effect of temperature on interaction between eggs and spermatozoa of sea urchin. Biol Bull. Mar. Biol., 166: 68-77.

O'Connor, C. and Mulley, J. C. 1977. Temperature effects on periodicity and embryology, with observations on the population genetics of the aquacultural echinoid Heliocidaris tuberculata. Aquaculture, 12: 99-114. 
O'Connor, M. I., Bruno, J. F., Gaines, S. D., Halpern, B. S. and Lester, S. E. 2007. Temperature control of larval dispersal and the implications for marine ecology, evolution and conservation. Proc. Natl. Acad. Sci. U. S. A., 104: 1266-1271.

Parvez, M. S., Rahman, A. M. and Yusoff, F. M. 2016a. Status, prospects and potentials of echinoids sea urchin in Malaysia. Int. J. Chem. Env. Biol. Sci., 4(1): 93-97.

Parvez, M. S., Rahman, A. M., Fatimah, M. Y. and Arshad, A. 2016b. Status, prospects and potentials of the commercially important species of sea urchin, Tripneustes gratilla (Linnaeus 1758) in Malaysia. Int. J. Biol. Ecol. Env. Sci., 5(1): 50-54.

Poloczanska, E. S., Babcock, R. C., Butler, A., Hobday, A. J., Hoegh-Guldberg, O., Kunz, T. J., Matear, R., Milton, D. A., Okey, T. A. and Richardson, A. J. 2007. Climate change and Australian marine life. Ocean. Mar. Biol., 45: 407-478.

Przeslawski, R., Ahyong, S., Byrne, M., Woerheide, G. and Hutchings, P. 2008. Beyond corals and fish: the effects of climate change on non-coral benthic invertebrates of tropical reefs. Global Change Biology, 14: 2773-2795.

Pulz, O. and Gross, W. 2004. Valuable products from biotechnology of microalgae. Appl. Microbiol. Biotechnol., 65(6): 635-648.

Rahman, M. A. and Uehara, T. 2004. Interspecific hybridisation and backcrosses between two sibling species of Pacific sea urchins (Genus Echinometra) on Okinawa intertidal reefs. Zool. Stud., 43(1): 93-111

Rahman, M. A., Uehara, T. and Aslan, L. M. 2000. Comparative viability and growth of hybrids between two sympatric species of sea urchins (Genus Echinometra) in Okinawa. Aquaculture, 183: $45-56$.

Rahman, M. A., Uehara, T. and Rahman, S. M. 2002. Effects of egg size on fertilisation, fecundity and offspring performance: A comparative study between two sibling species of tropical sea urchins (Genus Echinometra). Pakistan J. Biol. Sci., 5(1): $114-121$.

Rahman, M. A., Uehara, T. and Aslan, L. M. 2005. Growth and heterosis of hybrids of two closely related species of Pacific sea urchins (Genus Echinometra) in Okinawa. Aquaculture, 245: $121-133$

Rahman, S., Rahman, M. A. and Uehara, T. 2007. Effects of temperature on early development of the sea urchin Echinometra mathaei from the intertidal reef of Okinawa Island, Japan. Galaxea JCRS, 9: 35-48.

Rahman, M. A., Amin, S. M. N., Yusoff, F. M., Arshad, A., Kuppan, P. and Shamsudin, M. N. 2012a. Length weight relationships and fecundity estimates of long-spined sea urchin, Diadema setosum from the Pulau Pangkor, Peninsular Malaysia. Aquat. Ecosys. Health Manage., 15(3): 311-315.

Rahman, M. A., Yusoff, F. M., Arshad, A., Shamsudin, M. N. and Amin, S. M. N. 2012b. Embryonic, larval and early juvenile development of the tropical sea urchins, Salmacis sphaeroides (Echinodermata: Echinoidea). Sci. World J., 1-9.

Ridgeway, K. R. 2007. Long-term trend and decadal variability of the southward penetration of the East Australian Current Geophy. Res. Lett., 34(13): L13613.

Rupp, J. H. 1973. Effects of temperature on fertilisation and early cleavage of some tropical echinoderms, with emphasis on Echinometra mathaei. Mar. Biol., 23: 183-189.

Sarifudin, M., Rahman, M. A., Yusoff, M. F., Arshad, A. and Tan, S. G. 2016. Effects of temperature on the embryonic and early larval development in tropical species of black sea urchin (Leske, 1778). J. Environ. Biol. (special Issue), 37: 1-12.

Sewell, M. A. and Young, C. M. 1999. Temperature limits to fertilisation and early development in tropical sea urchin Echinometra lucunter. J. Exp. Mar. Biol. Ecol., 236: 291-305.

Seifullah, R. D., Ankudinova, I. A. and Kim, E. K. 1995. Seksual'noeprovedeniemuzhchin (sexual behavior of men). IzdvoYaguar, Moscow.

Southward, A. J., Hawkins, S. J. and Burrows, M. T. 1995. Seventy years' observations of changes in distribution and abundance of zooplankton and intertidal organisms in the Western English Channel in relation to rising sea temperature. J. Therm. Biol., 20: $127-155$

Unsworth, R. K. F., Cillen, L. C., Pretty, J. N., Smith, D. J. and Bell, J. J. 2010. Economic and subsistence values of the standing stocks of seagrass fisheries: Potential benefits of no-fishing marine protected area management. Ocean Coast Manage., 53: $218-224$.

Walther, G. R., Post, E., Convey, P., Menzel, A., Parmesani, C., Beebee, T. J. C., Fromentin, J. M., Hoegh-Guldberg, O. and Bairlein, F. 2002. Ecological responses to recent climate change. Nature, 416: 389-395.

Weinberg, T., Russel, B. D., Moore, P. J., Ling, S.D., Smale, D. A., Campbell, A., Coleman, M. A., Steinberg, P. D., Kendrick, G. A. and Connel, S. D. 2011. Impacts of climate change in a global hotspot for temperate marine biodiversity and ocean warming. J. Exp. Mar. Bio. Ecol., 400: 7-16.

Yur'eva, M. I., Lisakovskaya, O. V., Akulin, V. N. and Kropotov, A. V. 2003. Gonads of sea urchins as the source of medication stimulating sexual behaviour. Russian J. Mar. Biol., 29(3): 189-193.

Date of Receipt : : 01.08.2017

Date of Acceptance : 11.06 .2018 